\title{
The Deposit Insurance System Under Regulatory Consolidation: Lessons From The Savings And Loan Disaster
}

\author{
Philip L. Bransford, $J r^{\dagger}$
}

Philip Bransford is a master's degree candidate studying economic policy at The George Washington University's Department of Public Administration. He has worked as an associate producer for a public affairs discussion program at KQED-FM, a public radio station in northern California, and has worked for the MacNeil/Lehrer Newshour.

\section{The Origins of Regulating Depository Institutions}

The stock market crash of 1929 and the subsequent economic Depression of the 1930s brought the banking system in the United States to its knees. Banks were under assault from all sides: vast portions of bank industry assets had been invested on Wall Street and after the crash the value of these assets collapsed. In the worsening economic conditions, many borrowers failed to meet their loan payments on time, eventually declaring bankruptcy and leaving the banks holding worthless loan notes. Depositors, fearful that their savings were in jeopardy, descended on banks in droves, demanding instant liquidation of their checking and savings accounts. Thousands of banks failed - some within mere hours of "runs" by depositors. This combination of events resulted in the destruction of millions of dollars in private deposits. Thus, during the economy's most vulnerable moment, when banks needed capital to keep the economy moving, the nation's money supply was severely constricted.

Two new regulatory agencies, the Federal Deposit Insurance Corporation (FDIC) and the Federal Savings and Ioan Insurance Corporation (FSLIC), were bom out of this catastrophe. As mandated by the Banking Act of 1933, the FDIC guaranteed that up to $\$ 2,500$ per depositor at participating banks would be protected by the federal government no matter how troubled the economy or banks became. The FDIC maintains this insurance fund (which now backs deposits up to $\$ 100,000$ ) by charging premiums to banks responsible enough to qualify. To keep this coverage, these participant banks must comply with FDIC regulations and directives, most of which are designed to keep banks from engaging in "unsafe and unsound" practices.

A regulatory and insurance system for thrift depositors also grew from the ashes of the Great Depression. This system paralleled that created for banks. As mandated by the National Housing Act of 1934, the FSLIC originally guaranteed up to $\$ 5,000$ per thrift depositor and eventually protected to the same $\$ 100,000$ level as bank depositors.

Despite these broad similarities, however, the banking and thrift regulatory systems had one key difference: structure. Unlike the banking system, in which deposit insurance and discount lending functions are administered separately by the FDIC and the Federal Reserve, respectively, the home lending system had both functions administered by one entity: the Federal Home Loan Bank Board (FHIBB or the "Bank Board"). Thus, the Bank Board set the safety and soundness standards by which thrifts would be insured.'

\section{The Functions of Regulating Depository Institutions}

These two federal agencies, the FDIC and the FHIBB, are part of an overall regulatory scheme for depository institutions which has three "core functions:" central banking, deposit insurance, and day-to-day supervision. ${ }^{2}$

Most industrialized countries, including the United States, have given central banks the power to control the size of the money supply by setting interest rates, also referred to as the establishment of "monetary policy." In addition, central banks have traditionally maintained reserve requirements and served as a "lender of last resort" by providing emergency loans to unstable banks or thrifts. These activities have been performed for most of the 20th century by two government agencies in the United States: the Federal Reserve and the Federal Home Ioan Banks.

The deposit insurance function of government is largely that of maintaining the insurance funds and overseeing the liquidation of dead or dying institutions whose 
deposits are covered by insurance. Both the FDIC and, until recently, the FSLIC have performed these functions.

The remaining duties performed by the government in regulating depository institutions are supervisory. In general, these oversight duties involve authorizing the establishment of new institutions (chartering), approving the growth of those already operating, and conducting regular examinations to gauge the financial health of each institution and that of the industry as a whole. ${ }^{3}$ Unlike the first two core functions of regulation, no single agency of govemment is responsible for supervision. Instead, all the federal agencies mentioned so far (and some which will be described later) have shared in the oversight of thrifts and banks.

Despite functioning reasonably well for nearly half a century, this regulatory scheme was far from perfect. To understand the extent of these imperfections and how they might be eliminated, this article will evaluate the government's deposit insurance function for regulating banks and thrifts in the context of the savings and loan crisis of the 1980 s, the most severe test of the deposit insurance system since its creation. After examining this crisis, this article will explore the extent to which merging the supervisory functions of various federal agencies will improve the overall effectiveness of the deposit insurance system.

\section{The Savings and Loan Crisis}

During the late 1970 s and early 1980 s, a series of events brought the deposit insurance system for savings and loans to near collapse. In 1979, the Federal Reserve Board discontinued explicitly setting interest rates, its usual method of battling inflation, and concentrated on slowing the growth of the money supply, thus letting the credit markets determine interest rates. The result was an interest rate explosion." Such high interest rates could not be offered by savings and loans, however, because these institutions were required by the Interest Rate Control Act of 1966 to fund their low-risk mortgage lending with low-yield consumer deposits. ${ }^{5}$ Sky-high interest rates meant that the best returns offered to investors during this period were in money market mutual funds and higher-yielding securities offered by Wall Street investment firms. Savings and loan depositors soon found that the interest earned on their savings accounts was far outstripped by inflation; thus, as long as depositors kept their savings in thrifts, their money lost value. To avoid this, depositors began closing accounts in droves, leaving behind a weakened savings and loan industry.

Under both the Carter and Reagan administrations, the federal government attempted to strengthen the thrift industry with a hazardous combination of increased deposit insurance coverage and banking deregulation. In other words, the government took on responsibility for more thrift deposits while simultaneously relaxing the rules under which thrifts could invest these deposits. This trend began in 1978 when Congress passed the Financial Institutions Regulatory and Interest Rate Control Act which expanded FSLIC coverage for individual retirement deposits from $\$ 40,000$ to $\$ 100,000$ per account. Two years later, the remaining deposits at savings and loans were insured up to $\$ 100,000$ by the Depository Institutions Deregulation and Monetary Control Act of 1980. Congress shortly thereafter passed the Garn-St. Germain Depository Institutions Act of 1982, allowing thrifts to take much greater risks and seek higher yields when investing depositors' money. In addition, the FHLBB relaxed enforcement of accounting standards which allowed institutions to cover up weaknesses in their portfolios. Not to be outdone, many states - especially those suffering disproportionately from the recessionary economy of the early 1980s - exceeded the federal government's standards when deregulating state-chartered thrifts. Thus, the federal government became liable for insuring more deposits while allowing these deposits to be invested with greater risk. ${ }^{6}$

\begin{tabular}{l}
\hline \hline "The FSLIC - and later Congress - \\
faced a choice between two evils: \\
whether to shut down insolvent \\
thrifts and pay off their depositors \\
immediately or bave the FSLIC \\
continue operating these tbrifts, thus \\
buying time to recruit new owners."
\end{tabular}

As the nation started to recover from the recession of 1982, savings and loan executives took advantage of the emerging laissez-faire regulatory environment by committing federally insured deposits to reckless and sometimes illegal investment schemes. In some of the worst cases, such as that of Charles Keating, Jr.'s Lincoln Savings and Loan, home mortgage lending was the last priority of business. Instead, thrifts like Lincoln engaged in insider trading, rigged fraudulent real estate deals, and sheltered their profits from the IRS with labyrinthine accounting used by their own holding companies.? 
Despite notorious examples like Lincoln, former FHLB Board Member Lawrence White argues convincingly in his book, The SEL Debacle, that the thrift failures during the 1980s resulted more from carelessness than fraud. White states:

These thrifts largely failed because of an amalgam of deliberately high-risk strategies, poor business judgments, foolish strategies, excessive optimism, and sloppy and careless underwriting, compounded by deteriorating real estate markets. ${ }^{B}$

The result was the insolvency of 364 thrifts by 1988 . Although these failures represented only 12 percent of all insured thrifts at the time, they nevertheless brought the FSLIC to bankruptcy, effectively leaving every thrift in the nation - billions of dollars in savings and loan deposits - uninsured.?

In 1985, as the number of ruptured savings and loans grew beyond the government's ability to insure deposits, the FSLIC - and later Congress - faced a choice between two evils: whether to shut down insolvent thrifts and pay off their depositors immediately or have the FSLIC continue operating these thrifts, thus buying time to recruit new owners. Had the insolvent savings and loans been closed immediately, the FSLIC would have emptied its $\$ 6$ billion of reserves in a matter of weeks and would still have $\$ 9$ billion in deposit insurance claims to fulfill just for that year. ${ }^{10}$ Under this scenario, Congress would be forced to replenish the thrift insurance fund with revenue from taxes, an exceedingly unpopular move during a period of accumulating national debt. Despite these problems, a congressionally-backed emergency plan to meet the crisis head-on might have saved billions of dollars in lost deposits over the long run."

\section{The Bank Board Under Edwin J. Gray}

The first response by the Bank Board to the rapidly emerging crisis was to eliminate the source of growth for reckless thrifts. To do this, the FHLBB promulgated a regulation barring thrifts from accepting brokered deposits, those accounts established by stockbrokers for clients seeking the highest possible rate of return while still enjoying deposit insurance protection. By regulating this activity, the Bank Board hoped to slow the explosive growth of irresponsible thrifts and redirect the industry back toward mortgage lending. Although well-intentioned, this first move by Edwin J. Gray, the chairman of the Bank Board at that time, did more to unify opposition in the White House and Congress than anything else. Upon hearing of Gray's plans, Treasury Secretary
Donald Regan dispatched his deputy, R.T. McNamar, to talk Gray out of implementing rules against brokered deposits. At the other end of Pennsylvania Avenue, over $200 \mathrm{mem}-$ bers of Congress co-sponsored a non-binding resolution demanding that the Bank Board back down on its order to prohibit brokered deposits. ${ }^{12}$ Despite these efforts by the Reagan administration and Congress, the judicial branch of government was the only institution capable of stopping Gray from implementing his plan. Within five months of being promulgated, the regulation against brokered deposits was enjoined by a Federal District Court. ${ }^{13}$ Thus, in the first round of the fight against FSLIC's political and industry foes, Gray had swung and missed, wasting precious political capital in the process.

This initial failure haunted Gray as he attempted to promote additional reforms. In late 1984, with the worst of the savings and loan disaster beginning to appear on the horizon, the Bank Board sought to increase the number of thrift examiners on its staff. To accomplish this, Gray first had to seek the blessing of the director of the Office of Management and Budget, David Stockman - arguably the Reagan administration's most zealous advocate for reducing the federal bureaucracy. Gray's pro-regulation reputation (established after the brokered deposits fiasco) and his request for more bureaucrats conflicted with Stockman's deregulatory ideology.

Gray's political stature with the recently re-elected Reagan administration was so diminished that Stockman would not meet with Gray directly. Instead, Stockman sent his deputy, Constance Horner, to meet the head of the Bank Board. When the OMB eventually rejected the appeal for new examiners, Gray implemented a contingency plan: the examiners would be transferred out of the congressionally-funded FSLIC and into the industryfunded Federal Home Loan Banks. In so doing, Gray had neatly bypassed the need for OMB approval. ${ }^{14}$

\section{Keeping the FSLIC Solvent}

Despite the initial objections of the Reagan administration to Gray's emergency strategy, there was one plan of action about which the White House and the Bank Board eventually agreed: the thrift insurance fund must be replenished. Given the rate at which savings and loans were going out of business, the Bank Board argued, more money would have to be given to the insurance fund in order to avert an industry-wide panic. Although the White House recognized this problem, the Reagan administration would only endorse a recapitalization plan if the associated costs neither appeared in the federal budget nor were 
paid for by tax increases. Under these conditions, the White House and the Bank Board compromised on a recapitalization plan in which the FSLIC would be replenished with $\$ 15$ billion in borrowed Treasury bonds. Although $\$ 15$ billion would not have resolved the crisis in 1986, the White House-Bank Board compromise was still the only serious option being debated at the time. ${ }^{15}$

Unfortunately, the election campaigns of several key members in the House and Senate were financed by savings and loan executives, so the recapitalization plan was destined to go nowhere. ${ }^{16}$ Members like then-House Majority Leader Jim Wright (D-Texas) threatened not to vote for the plan until the FHLBB refrained from using its supervisory power in ways which reduced thrift profits." Perhaps the most widely known case of Congressional interference of this kind involved five senators "captured" (according to FHLBB meeting notes) in the act of pressuring thrift regulators to back off from their examination of Lincoln Savings and Loan and its owner, Charles Keating - a constituent, a campaign contributor to all five, and, in 1993, a convicted felon. ${ }^{18}$

The $\$ 15$ billion Reagan administration recapitalization plan eventually passed both Houses of Congress but died in conference committee. One year later, as the liquid assets of the FSLIC dipped below the $\$ 1$ billion level, a recapitalization plan was reintroduced by the Reagan administration. Although this bill only authorized $\$ 11$ billion in borrowing authority (theoretically making the proposal more acceptable to deficit-conscious law makers than the former $\$ 15$ billion plan), the legislation could be dislodged from an ambivalent Congress only when Reagan threatened to veto any recapitalization bill granting an insufficient level of borrowing. The bill Congress eventually passed, called the Competitive Equality Banking Act (CEBA), was signed by President Reagan in August of 1987.19

Enactment of CEBA in the summer of 1987 was no small feat. At that time, the public ire associated with the thrift crisis had not yet reached a boiling point and many important members of Congress were still under the influence of the savings and loan industry's political action committee money. Ironically, the Reagan administration, a proponent of getting government off the backs of business, emerged as the recapitalization bill's most effective advocate. ${ }^{20}$ Nevertheless, due to the accelerating pace of thrift insolvencies, the CEBA's relatively puny $\$ 11$ billion line of credit authorization was obsolete before the legislation was even signed. The estimated assets of either thinly capitalized or completely insolvent savings and loans exceeded $\$ 400$ billion by late $1988 .{ }^{21}$ Even if twothirds of these thrifts eventually survived, the FSLIC would undoubtedly need more than $\$ 11$ billion to keep the deposits of the other third from being lost.

\section{The Southwest Plan and the Appointment of M. Danny Wall}

Until Congress became serious about replenishing the thrift deposit insurance fund, the Bank Board was forced to rely on the second strategy mentioned earlier, that of encouraging the private sector to buy failed thrifts. In order for the Bank Board to uphold its obligation to depositors, however, these thrifts would have to be sold with great speed. Thus, cautious buyers with limited supplies of cash would not be recruited as avidly as wealthy corporations and individuals - especially those able to make quick business decisions. To lure this target population, the Bank Board offered tax reductions and, in some cases, guaranteed short-term profits. ${ }^{2}$ Many critics of this strategy invoked Yogi Berra's maxim, "it's deja vu all over again," when comparing the former savings and loan owners with the new, Bank Board-recruited buyers; both groups were privileged, reckless, and irresponsible, these critics claimed.

\begin{tabular}{c}
\hline \hline "With George Bush securely in \\
the White House and Democratic \\
incumbents safely in their \\
offices after the election of 1988, \\
the political debate could at \\
last begin over who was to \\
blame for the disaster."
\end{tabular}

By the time this strategy (called the "Southwest Plan" because most of the thrifts under FHLBB conservatorship at the time were in southwestern states) was put into high gear, Edwin Gray had long since concluded his term as chairman of the Bank Board. In his place, President Reagan appointed M. Danny Wall, a former aide to Senator Jake Garn (R-Utah). As staff director of the Senate Banking Committee in 1982, Wall had helped draft one of the key laws of early savings and loan deregulation: the Garn-St. Germain Act.23

Danny Wall presided over the Bank Board during what was arguably the thrift insurance system's darkest period. As the media became more aware of the depth of the 
crisis, the saga of the savings and loan disaster was told less as an arcane business story and more as a massive failure of government. With George Bush securely in the White House and Democratic incumbents safely in their offices after the election of 1988 , the political debate could at last begin over who was to blame for the disaster. However, with both parties indicted by their past actions (Republicans for pushing to deregulate the industry in the early 1980s and Democrats for protecting corrupt thrifts more recently), the partisan debate could go only so far before a scapegoat needed to be found. The Bank Board proved to be an attractive-target. Both the confusing logic of the Southwest Plan and Wall's inability to provide a reliable cost estimate for the disaster generated criticism. ${ }^{24}$

\section{The Financial Institutions Reform,} Recovery, and Enforcement Act

One of President Bush's first legislative proposals after assuming office was a bill to completely overhaul the thrift regulatory system by dissolving both the FSLIC and the Bank Board. The Bush plan, called the Financial Institutions Reform, Recovery, and Enforcement Act (FIRREA), sought to centralize the deposit insurance system for thrifts and banks by consolidating the functions of the politically unpopular Bank Board and FSLIC with those of the less stigmatized Federal Deposit Insurance Corporation (FDIC) and the Department of the Treasury. FIRREA would also strengthen the FDIC's independence, jurisdiction, and regulatory powers; infuse the savings and loan deposit insurance fund with a $\$ 50$ billion credit line from the Treasury and increase premiums charged to insured thrifts; and strengthen laws and expand penalties for those convicted of illegal activity associated with a thrift. ${ }^{25}$

Of all FIRREA's parts, Title II pertained most directly to the insurance of deposits in the savings and loan industry. This section would redistribute many of the powers of the FSLIC and the FHIBB to two new creations: the Resolution Trust Corporation (RTC) and the Office of Thrift Supervision (OTS). The RTC would oversee asset liquidation of insolvent savings and loans while the OTS was to regulate the thrift industry in general. Assuming the thrift clean-up would only take four years, the authors of FIRREA planned for the RTC to be subsumed into the FDIC in 1993 . The OTS, on the other hand, would remain the thrift industry's permanent regulator, becoming part of the Department of the Treasury.

Title II of FIRREA also expanded the independence of the FDIC as a regulatory agency and required the FDIC to insure thrift deposits through the Savings Association
Insurance Fund (SAIF). The legislation also gave the FDIC power to borrow from the Treasury in order to keep the insurance fund solvent. Finally, the FDIC was given broad powers to determine which thrifts should be insured and to specify the requirements these thrifts must meet to maintain their insurance. In general, no insured savings and loan would be allowed to engage in any practice the FDIC judged "unsafe or unsound."26

By the time the Bush administration introduced FIRREA in February of 1989, the political relationship between Congress and the Bank Board had shifted 180 degrees. Whereas Congress once ignored the Bank Board's arguments for tougher regulation of thrifts, the legislators were now tripping over themselves to strengthen the statutory powers of thrift regulators. Although members of Congress had let the thrift recapitalization bill co-authored by the Bank Board languish for two years, the legislators now chided the Bank Board for not providing an accurate estimate of the FSLIC's needs so that a full recapitalization of the insurance fund could take care of the problem once and for all.

Nowhere was this change in the relationship more apparent than on the floor of Congress after FIRREA emerged from committee mark-up. Instead of pressuring regulators behind closed doors to ease up on their friends in the thrift industry, representatives and senators now rushed to the floors of their chambers, hoping to include amendments to FIRREA that would tighten regulations on thrifts, increase the power of the regulators, or expand the criminal sentences for fraudulent thrift managers. ${ }^{27}$ Perhaps the most ironic symbol of the transformation was the acceptance - without objection or much debate - of an amendment by Senator Frank Murkowski (R-AK) prohibiting thinly capitalized thrifts from receiving brokered deposits. This was the first tool Edwin Gray tried to use when the crisis emerged - the very tool that 200 members of the House opposed through simple resolution. The savings and loan crisis had come full circle.

FIRREA passed the House and the Senate by wide margins on August 4, 1989, and President Bush signed the bill into law three days later. Thus, after more than half a century of history, the Federal Savings and Loan Insurance Corporation and the Federal Home Loan Bank Board ceased to exist.

\section{Keeping the Insurance Fund Solvent}

Those believing that FIRREA would put a stop to the hemorrhaging within the nation's savings and loan industry were quickly disappointed. In April, 1990, the General Accounting Office (GAO) warned that several factors inadequately addressed in FIRREA - could contribute to 
an intensifying deposit insurance crisis. One such factor was the oppressive economic environment for struggling savings and loans just after FIRREA's enactment. Market interest rates remained stubbomly high despite the economy's deterioration. Neither businesses nor consumers were inclined to borrow. Unless Congress allocated more funding to bail out the latest wave of failed thrifts, the GAO predicted the insolvency of the thrift clean-up fund. ${ }^{23}$ In 1991, as another recession descended on the economy, Congress reluctantly responded to the GAO's earlier warning by replenishing the RTC fund twice, once with $\$ 30$ billion and then again with $\$ 25$ billion. The second appropriation was made on the condition that any funds not used by April 1992 would revert back to the Treasury. Thus, when the target date arrived, the RTC was forced to turn over $\$ 18$ billion despite the fact that the RTC was still managing dozens of thrifts which it could not afford to close. As a result of this forced refund, the RTC was bankrupt less than one year before it was supposed to dissolve, as required by FIRREA. Nothing was done to replenish the RTC fund until after the presidential election of 1992, neglect which the RTC estimated cost taxpayers six million dollars per day. ${ }^{29}$ Congress finally addressed the problem just before recessing for the winter holidays in 1993. The same amount of money the RTC retumed to the Treasury the year before ( $\$ 18$ billion) was given back, along with an extended deadline (the end of 1995) to clean up the remaining insolvent thrifts. ${ }^{30}$

"Given that the Federal Reserve and
the FDIC are responsible for central
banking and deposit insurance,
respectively, logic suggests that some
otber federal agency should be
responsible for supervision."

Sufficient funding for the RTC is one of two good reasons that the savings and loan bail-out will probably come to an end in the early 1990s. The other reason concerns the low interest rates generated by the Federal Reserve in response to the recession of 1990-91. Banks have historically been successful by "borrowing short and lending long" that is, by paying relatively low interest on depositors' accounts (selling six-month certificates of deposit in the money market, for example) and making long-term loans at relatively higher rates. So long as the long-term interest rates earned by banks exceeded the short-term rates paid by banks, the difference (net of expenses) represented a profit. Thus, the low-interest-rate environment of the early 1990s had a salutary effect on the banking and thrift industries by allowing many heretofore weak lenders to improve their balance sheets. ${ }^{31}$

\section{The Rationale for Additional Reform}

Although the industry outlook for depository institutions and their insurance funds now seems healthy after the worst of the savings and loan debacle, there are many lessons still to be learned. Some observers and policymakers have concluded that a complete solution to the savings and loan crisis extends beyond the replenishment of insurance funds and agency restructuring enacted thus far. To take full advantage of the chaotic history of the last decade, the argument goes, government must address weaknesses in the deposit insurance system which could only have been revealed during a period of such stress. Given that so many parts of the system broke down simultaneously during the thrift crisis - everything from accounting standards to agency-Congressional relations only reforms equal in scope might prevent disaster from recurring. Under such assumptions, the reforms instituted by FIRREA lack the full ability to protect against future meltdowns. Instead of simply repairing parts of the system in the midst of crisis (as FIRREA attempted), the government should redesign the regulatory framework for financial institutions using recent history as its guide.

Within this context, several proposals emerged in the winter of 1993-94 to reshape the regulatory structure for banks and thrifts. To better understand these proposals and why such changes might correct many of the structural weak- . nesses revealed during the savings and loan crisis, an expanded description is needed of thrif and bank regulation.

\section{Defining the Problem}

As mentioned earlier, the role of the federal government in regulating depository institutions centers on only three core functions: central banking, deposit insurance, and supervision. Given that the Federal Reserve and the FDIC are responsible for central banking and deposit insurance, respectively, logic suggests that some other federal agency should be responsible for supervision. Unfortunately, logic had little to do with the creation of the federal regulatory structure for banks and thrifts. As former FDIC Chairman $\mathrm{L}$. William Seidman has pointed out, the four federal agencies which share responsibility for bank and thrift supervision do so by virtue of "historical accident." ${ }^{32}$. These four agencies are the FDIC, the Federal Reserve, the OTS, and the 
Office of the Comptroller of the Currency (OCC). Adding to the complexity, federal oversight activity is duplicated at the state level with 50 agencies responsible for the regulation of state-chartered depository institutions. ${ }^{33}$ With the supervisory function scattered so haphazardly across the regulatory structure, an obvious problem over the decades has been the wasteful duplication of the government's efforts.

One example will show the extent of supervisory overlap. BankAmerica Corporation, a large bank holding company, owns a chain of nationally chartered banks, a group of statechartered banks, and a collection of savings and loans some of which have been bought from the RTC. The holding company is supervised by both the OTS and the Federal Reserve. Those branch offices with national charters are supervised by the OCC. The Federal Reserve supervises those state-chartered banks that are members of the Federal Reserve System (called "member banks"), while the remaining state-chartered banks (called "nonmember banks") are supervised by the FDIC. Finally, savings and loans operating under the BankAmerica umbrella are supervised by the OTS.

According to a recent report by the Department of the Treasury, regulatory overlap is not limited to large organizations like BankAmerica. The Treasury found that 58 percent of all U.S. banking organizations, holding 73 percent of the nation's assets, are supervised by two or more federal regulators. ${ }^{34}$ Moreover, as the trend toward industry consolidation continues, in which the nation's largest banks have been acquiring mid-sized regional banks and savings and loans, the vast majority of depositors in the country may soon have accounts with institutions facing the same redundant array of regulators as BankAmerica.

Calculating the exact cost to the taxpayer for such a duplicative supervisory structure is beyond the scope of this article. Nevertheless, the costs of maintaining such a system are unaffordable in this era of tight budgets. For example, one such unnecessary cost is that of operating separate headquarters in Washington, D.C., for all the federal regulators mentioned above. The Federal Reserve, the FDIC, and the OTS also maintain separate field offices across the country. Each of the four regulatory agencies employs thousands of examiners supported by large clerical staffs. Each agency also has separate directors, chairpersons, and other executives who must be nominated by the President and confirmed by the Senate.

Indirect costs to taxpayers are incurred in part by the amount of effort each agency must exert simply to understand and comply with changes in the law. To comply with FIRREA, for example, officials at the newly formed RTC found it necessary to map out the entire regulatory landscape for thrifts in an intricate flow chart resembling the circuitry of a computer micro-chip (see Appendix A) ${ }^{35}$ Instead of providing visual confirmation of the sound framework on which government rests, the RTC chart seems to symbolize the opposite.

Banks and thrifts also pay for redundancies in the regulatory structure. Despite attempts at coordinating activities * and sharing information, directives from the different regulators often conflict. In order to avoid violating the government's authority, banks and thrifts must choose between expensive options: attempting to comply with contradictory directives or litigating to have them removed. Ultimately, these costs tend to be passed on to the consumer in the form of higher fees.

\section{Reinventing the Regulatory Structure}

Over the last 50 years, several presidential administrations have called for the consolidation of the bank regulatory system. In particular, proposals have emerged under nearly all of the recent Republican administrations to take away the supervisory functions of the FDIC, the Federal Reserve, or both. ${ }^{36}$ More recently, key members of the House and Senate have introduced legislation that has captured the attention of the current White House. ${ }^{37}$

Following the submission of the National Performance Review by Vice President Gore in late 1993, the Clinton administration released its plan for "reinventing" the way the government regulates depository institutions. The original Clinton proposal called for consolidating the supervisory functions of all the federal regulatory agencies into one Federal Banking Commission (FBC or the "Banking Commission"), thus freeing the FDIC and the Federal Reserve to focus exclusively on insuring deposits and setting monetary policy, respectively. Under this proposal, the OCC and the OTS would be abolished and their functions taken over by the Banking Commission. ${ }^{35}$

Administration of the new Banking Commission would be handled by a five-member board consisting of the Secretary of the Treasury, a member of the Federal Reserve Board of Governors (to be designated by the Federal Reserve), and three additional presidential appointees not to be otherwise affiliated with the federal government. One of these three appointees would be designated by the President to be the chairperson of the Commission. ${ }^{39}$

The legislative version of the Clinton plan, called the Regulatory Consolidation Act (RCA) of 1994, was introduced in Congress during the spring of 1994 by Sen. Donald 
Riegle. Unlike the administration's original proposal, however, RCA would unfortunately preserve much of the Federal Reserve's current role in supervising banks - an amendment undoubtedly meant to quiet the Federal Reserve's strong opposition to the original Clinton plan. ${ }^{40}$

\section{Lessons from the Savings and Loan Disaster}

In addition to eliminating the waste and duplication mentioned earlier, system-wide consolidation similar in scope to the original Clinton proposal would rectify many of the weaknesses in the regulatory structure which were revealed during the savings and loan disaster. As will be shown, the closer the proposed Federal Banking Commission can be made to resemble the federal government's most effective and independent agencies, the better protected depositors and taxpayers will be from the adversity which afflicted savings and loans in the 1980s.

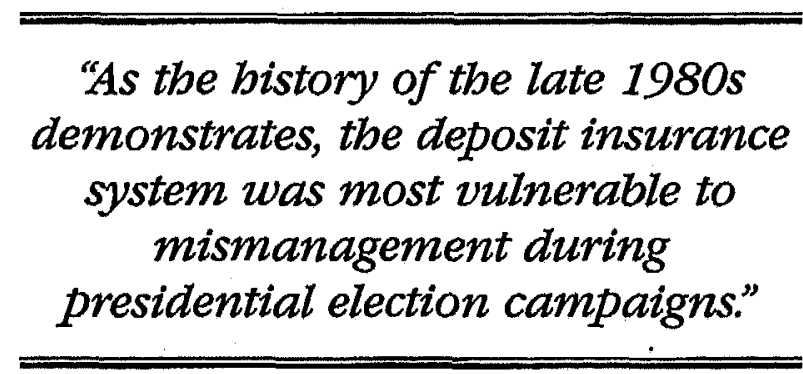

To understand how centralizing federal supervision will help prevent the recurrence of such a debacle, the following premise must first be accepted: the practices of thrifts are now sufficiently similar to those of banks. Where the market for credit was once clearly divided between home owners and other kinds of borrowers, most thrifts and banks currently provide similar customers with similar products. Thus, just as the supervision of both radio and television broadcasters is effectively provided by the Federal Communications Commission, the kind of supervision needed for both the thrift and banking industries is now comparable enough to justify a single regulator."

Merging thrift and bank regulators would also centralize information concerning the financial health and practices of multi-affiliated institutions like Charles Keating's Lincoln Savings and Loan. Instead of hiding high-risk or fraudulent activities in those subsidiaries overseen by the weakest regulators (a practice called "competition in laxity" or "forum shopping"), irresponsible institutions like Lincoln would find every part of their operations under the scrutiny of one agency. ${ }^{42}$
Perhaps the single greatest improvement to regulatory supervision stemming from agency consolidation would be the increased political clout that the chairperson of the Banking Commission could wield. Unlike the contempt the White House and Congress showed Edwin Gray when the savings and loan crisis first emerged, the chairperson of the Banking Commission should enjoy the same respect traditionally given to the chairperson of the Federal Reserve Board or to the head of the FDIC. In addition, future presidents might think twice before nominating (and future legislators might resist confirming) a controversial figure like Danny Wall to a position of great visibility and responsibility within the government.

Given the importance of preserving the Banking Commission's autonomy, the same six-year term of office granted to FDIC board members should be granted to the Commission's board members, instead of the fiveyear term proposed in the Clinton plan. In fact, RCA's greatest defect is the proposed four-year term for the chairperson of the Banking Commission. As the history of the late 1980s demonstrates, the deposit insurance system was most vulnerable to mismanagement during presidential election campaigns. Synchronizing the chairperson's term of office with the presidential election cycle may encourage leadership governed by politics instead of the best interests of depositors. ${ }^{.3}$ In addition, the political fault lines which developed during the savings and loan crisis should motivate Congress to remove the proposed position on the Banking Commission's board for the Secretary of the Treasury. As the aforementioned example of former Treasury Secretary Donald Regan suggests, the pressure on Treasury to ignore and understate the thrift crisis proved overwhelming."4 Given that current and future administrations are likely to continue facing political pressure to ignore important problems, the board of the Banking Commission should be made as free from this pressure as possible, thus encouraging early detection and disclosure of future crises.

The creation of a strong and independent FBC to supervise banks and thrifts will also improve the FDIC's ability to insure deposits. Currently, according to Clinton's Undersecretary of the Treasury, Frank Newman, this is because the FDIC is forced into a potential conflict of interest between insuring deposits and supervising institutions. When the insurance fund is well capitalized, Newman argues, the FDIC has an incentive to use supervisory power in order to "resist banking innovations." banking industry is healthy and the deposit insurance fund is large enough to handle almost any problem, the FDIC 
will discourage the kind of creative activity which markets need in order to stay healthy. Under these conditions, the FDIC behaves like a nervous lifeguard watching over an Olympic swim team. Although the swimmers are some of the best in the world and although there are plenty of life preservers at the ready, the lifeguard will not allow anyone to swim at a competitive speed.

The government's response to the emerging market for derivatives may by an example of this overly protective behavior. These specialized contracts, which are "derived" from underlying securities, are designed to protect consumers' portfolios from sharp swings in interest rates. Fearful of repeating another savings and loan-type disaster, regulators and law makers have voiced concerns about the increasing level of exposure many of the biggest banks are approaching due to the sale of derivatives. ${ }^{45}$ Despite this risk, one could argue that well-capitalized banks with sound reputations are being threatened with a potential rebuke by Congress and regulators for simply developing a profitable financial product that customers like.

On the other hand, Newman argues that when the insurance fund nears insolvency, the deposit insurance agency "has incentives to forbear." In other words, as hundreds of institutions begin to fail and the deposit insurance fund dwindles, the FDIC would become tolerant of risky business practices on the grounds that such practices might improve the industry's health. In terms of the aquatic analogy used earlier, imagine a large group of adolescent swimmers whose antics put them at risk of drowning. The lifeguard would then face the dilemma of having too many troubled swimmers and too few life preservers. In order to increase the chance of each swimmer's survival, the lifeguard might resort to dangerous forms of rescue, like allowing speed boats with dangling fishing nets to drag swimmers back to shore.

The Southwest Plan is an example of such risky behavior. With no hope for the recapitalization of the FSLIC by Congress, the Bank Board resorted to protecting deposits by selling government-controlled thrifts to anyone who would buy them - no matter how reckless these purchasers may have been in their past business practices. Newman concludes that separating supervisory and insurance functions in accordance with the Clinton plan will "eliminate these conflicts."

As compelling as Newman's argument for separating the supervisory and insurance functions may be, his analysis has been subject to the same criticism that arose when FIRREA split the government's thrift supervision function away from its deposit insurance function. At that time, critics claimed that bifurcating regulatory functions would also separate the government's two principal tools for maintaining the thrift industry's health: the carrot and the stick. Virtually all banks elect to have deposit insurance (the carrot) because the costs of not having it (lost customer deposits) are far greater than its premiums. Conversely, thrifts and banks do not want depositors to even speculate that their institution is under anything other than routine examination by government agencies (the stick) because customers might conclude that the institution is near insolvency. Therefore, if a single agency possesses the power to use both the carrot of deposit insurance and the stick of examination, such an agency will likely have more influence than if these two powers were divided between two separate agencies.

\begin{tabular}{c}
\hline "Despite many strong arguments \\
supporting a more rational \\
structure for regulating depository \\
institutions, bistory suggests that \\
no such reform will be enacted until \\
the depository system is in crisis." \\
\hline \hline
\end{tabular}

Although the Clinton plan would separate the government's supervisory and insurance functions, there are good reasons to conclude that such a separation would nevertheless increase the government's effectiveness at performing both. To understand this, it is first necessary to understand that any regulatory structure will separate the supervisory and insurance functions to some degree. For example, although the FDIC's Division of Supervision currently exists apart from all the agency's other components, a sufficient level of intra-agency cooperation and information flow exists for the agency to function as a whole. What makes the current regulatory structure problematic (in addition to the duplication and conflicts of interest already discussed) is the absence of this same level of cooperation and information flow between agencies, as opposed to within them.

To fully understand the discord generated by the current system to supervise banks and thrifts, consider the jurisdiction of the FDIC. The nation's deposit insurer currently supervises only those state-chartered banks choosing not to be members of the Federal Reserve System, thereby leaving 40 percent of all domestic banks (holding 76 
percent of banking assets) outside the FDIC's supervisory jurisdiction." Whatever effectiveness the government currently has in overseeing the 24 percent of assets held by FDIC-supervised banks would arguably increase if the agency taking over the FDIC's supervisory role could oversee all the institutions receiving insurance..$^{50}$

The FBC proposed by the Clinton administration would be such an agency. By providing a single source of information to the FDIC about all the depository institutions receiving insurance, as the Banking Commission would be required to do by law, then the government as a whole might more skillfully keep banks and thrifts healthy while simultaneously insuring deposits. ${ }^{51}$ The FDIC would also have an easier time coordinating activities with other agencies because there would be fewer federal agencies with which to cooperate. Despite all these assurances, if the FDIC were still dissatisfied with the quality of examinations or the flow of information provided by the Federal Banking Commission, the FDIC's current examination and enforcement power would be retained as "back-up authority" under the Clinton plan."

\section{Conclusion}

Despite many strong arguments supporting a more rational structure for regulating depository institutions, history suggests that no such reform will be enacted until the depository system is in crisis. As has been described, the deposit insurance system was created to calm panicked depositors during a period of unprecedented economic stress. All of the major reforms since then were spurred by the threat of disaster as well. The thrift deregulation of the early 1980s was enacted in order to save the industry from the damaging effects of inflation. The re-regulation and agency consolidation of the late 1980 s was instituted in order to protect the industry from its own improprieties. Neither the inflation nor the same level of reckless abuse of the 1980s exists now. Nevertheless, if we as a nation can learn from the past and leave behind our tendency to react to crises, the relatively secure environment of the present may well be the best time to reshape the regulatory structure for banks and thrifts. *

\section{Notes}

† I wish to thank my editor, Mark Taylor, for his helpful suggestions and sound advice. I also wish to thank Dr. Susan J. Tolchin whose assignment inspired this article. Finally, I wish to thank Deborah Bransford, Alan Adolphson, and Kristin Teigen for their unfailing support.

1 Lawrence White, The SEL Debacle (New York: Oxford University Press, 1991), pp. 53-56.

2 Undersecretary Frank Newman, Consolidating the Federal Bank Regulatory Agencies (Washington, D.C.: Department of the Treasury, November 23, 1993), pp. 7-8.

3 To promote better understanding of the regulatory structure for banks and thrifts, the Federal Reserve Bank of New York published a chart depicting how state and federal agencies perform twelve : basic regulatory functions. Excluding deposit insurance and central banking activities, these functions include chartering and licensing; intra-state and inter-state branching; intra-state and inter-state mergers, acquisitions, and consolidations; supervision and examination; safety, soundness, and prudential limits; and, finally, consumer protection rule making and enforcement. See Federal Reserve Bank of New York, Depository Instilutions and Their Regulators (New York: Federal Reserve Bank of New York, April 1990).

4 William Greider, Secrets of the Temple (New York: Simon and Schuster, 1987), pp. 104-123.

5 Greider, p. 133; White, p. 62.
${ }^{6}$ House of Representatives Report No. 54(I), 101st Cong., 1st Sess., reprinted in United States Code Congressional and Administrative News, 1989, Public Law 101-73 Legislative History (St. Paul, Minn.: West Publishing Company, 1990), pp. 294-298.

7 Stephen Pizzo, Mary Fricker, and Paul Muolo, Inside Job (New York: Harper Perennial, 1991), pp. 350, 400-403, and 411-412.

8 White, p. 117.

9 House Report No. 54(1), p. 303.

10 White, p. 135.

11 Some observers have suggested that the recapitalization of the FSLIC would only have cost $\$ 20$ billion if Congress demonstrated the courage to intervene at the first signs of crisis. As early as 1985, the Bank Board itself estimated the cost of resolving failed savings and loans would only have been between $\$ 45$ and $\$ 50$ billion, according to R. Dan Brumbaugh, Jr., a former Bank Board economist. See Robert Sherrill, "The Looting Decade," The Nation, November 19, 1990, p. 608, and R. Dan Brumbaugh, Jr., in written testimony before the Senate Banking Committee, March 4, 1994, p. 12 .

12 Pizzo, Fricker, and Muolo, pp. 106 and 352.

13 Seven months later an appellate court upheld the district court's ruling in FAIC Securities Inc. v. U.S. 595 F. Supp. 73 (1984), 753 F. 2nd 166 (1985), 762 F. 2nd. 352 (1985). See White, p. 127. 
14 Pizzo, Fricker, and Muolo, pp. 353-355.

15 White, pp. 136-137.

16 Pizzo, Fricker, and Muolo, p. 352.

17 Brooks Jackson, Honest Graft (Washington, D.C.: Farragut Publishing Co., 1990), p. 281-286. Jackson quotes Wright in a cryptic admission that his bullying of regulatory agencies "is the kind of thing most congressmen" do almost every day for some private citizen or another."

${ }^{18}$ The five senators were Alan Cranston (DCA), Dennis DeConcini (D-AZ), John Glenn (D-OH), John MoCain (R-AZ), and Donald Riegle (D-MD). Although Keating could vote for only one of these senators, the holdings and major investments of Linooln were scattered throughout the jurisdictions of all five See Pizzo, Fricker, and Muolo, pp. 410 and 513-525; Richard Stevenson, "Keaing Convicted of Securities Fraud in S\&I's Collapse," New York Times, Deoember 5, 1991, p. A1; James Granelli, "Keating, Son Guilty of Federal Charges," Los Angeles Times January 7, 1993, p. D1.

19 White, pp. 139-140.

20 Perhaps the Reagan administration needed a victory, no matter how small, to use as political cover against criticisms about the savings and loan mess during the upcoming presidential election campaign of 1988 in which then-Vice-President George Bush was the Republican candidate.

21 Congress defined a thinly capitalized thrift as having a capital-to-assets ratio of 3 percent or less, using generally accepted accounting principles. See House Report No. 54(D), p. 303.

22 Sherrill, p. 610.

23 Pizzo, Fricker, and Muolo, pp. 420-421.

24 The House Banking Committee Report accompanying the Bush savings and loan reform plan includes this scathing criticism: "Under M. Danny Wall, the Federal Home Loan Bank Board continually underestimated the financial difficulty facing the FSLIC and the thrift industry. One of the major factors undermining this Committee's confidence in the Bank Board has been Mr. Wall's dismal record of measuring the magnitude of the FSLIC problem." See House Report No. 54(I), p. 305.

25 Financial Institutions Reform, Recovery, and Enforcement Act of 1989, Pub. L. No. 101-73, 103 Stat. 183 (codified in scattered sections of 12 and 15 U.S.C.); White, pp. 176-180, 183-184, 195.

26 Financial Institutions Reform, Recovery, and Enforcement Act, Sections 201-226, 103 Stat. at 187-277; White, pp. 176-180.

27 U.S. Congress, House, various representatives debating H.R. 1278, 101st. Cong., 1st Sess., Congressional Record (June 14-15, 1989), pp. 11777-11804 and 11957-12167; U.S. Congress, Senate, various senators debating S. 413, 101st. Cong., 1st Sess., Congressional Record (April 17-19, 1989), pp. 6682-6703, 6887-6900, and $7110-7254$.
28 Charles A. Bowsher, Document No. GAO/T-AFMD-90-15, Resolving the Savings and Loan Crists (Washington, D.C.: U.S. GAO, April 6, 1990), pp. 2-5.

29 "S\&L Bailout Funding Dries Up," Congressional Quarterly Almanac, 1992 ed., Vol. 48 (Washington, D.C.: Congressional Quarterly, Inc., 1992.), p. 115-116.

30 Jerry Knight, "House Approves Funds to Finish Thrift Cleanup," Washington Post, November 23, 1993.

31 James Barth and Dan Brumbaugh, Jr., "Merging Regulators Will Help Banks Compete," American Banker, December 2, 1993, p. 3.

32 L. William Seidman, "A New Way to Govem Banks," Wall Street Joumal, February 3, 1994.

33 This combination of state and federal regulatory structures is often referred to as the "dual banking system."

${ }^{34}$ Newman, p. 14. The Federal Reserve paints a less duplicative picture of the industry, arguing that only 26 percent of depository institutions have two or more primary regulators. Nevertheless, the Fed's own data shows that a clear majority of the industry's assets ( 63 percent) falls under the jurisdiction of two or more supervisory agencies. In fact, the Federal Reserve suggests that the Clinton administration has understated (by one percent) the extent of regulatory overlap for those institutions with four regulators. The Fed suggests that nearly three percent of all institutions are overseen by four federal regulators while the Treasury holds that only two percent of all institutions have four regulators. See Board of Governors of the Federal Reserve System, The Vieus of . the Board of Governors of the Federal Reserve System on the Consolidation of Bank Supervision and Regulation (Washington, D.C.: Federal Reserve System, March 1994), p. A-13.

35 Resolution Trust Corporation, Record No. 6901, FIRREA Functional Interrelationships (Washington, D.C.: U.S. RTC, August 8, 1989), pp. 1-2; White, pp. 189-192.

36 During the Nixon administration, the Hunt Commission recommended taking supervisory powers away from the Federal Reserve, the FDIC, and the OCC. During the Ford administration, the Financial Institutions, Supervision, Regulation, and Insurance Subcommittee of the House Banking, Currency, and Housing Committee conducted hearings on regulatory reform. Their report, entitled Financial Institutions and the Nation's Economy (FINE), recommended the consolidation of all federal bank regulatory agencies-including the National Credit Union Administration into one Federal Depository Institutions Commission. During the Reagan administration, then-Vice-President George Bush led the Task Group on Regulation of Financial Services. The Task Group's report, entitled Blueprint for Reform, recommended the creation of the Federal Banking Agency which would assume all the FDIC's supervisory functions and some of the Federal Reserve's. See Andrew Carron, Reforming the Bank Regulatory Structure 
(Washington, D.C.: The Brookings Institution, 1984) pp. 43-44, 4648, 51-52; U.S. Department of the Treasury, Modernizing the Financial System (Washington, D.C.: GPO, February 1991), p. XIX-8.

37 Representative Henry B. Gonzalez (D-TX), the chairman of the House Banking Committee, has introduced H.R. 1214 and Senators Donald Riegle (D-MI) and Alfonse D'Amato (R-NY), the chairman and ranking minority member, respectively, of the Senate Banking Committee, have introduced S. 1633. See H.R. 1214, 103rd Cong., 1st Sess. (1993), and S. 1633, 103rd Cong., 1st Sess. (1993).

38 Newman, p. 7.

39 Ibid., p. 8; S. 1895, The Regulatory Consolidation Act of 1994, 103rd Cong., 2nd Sess., reprinted in the Congressional Record, (March 8, 1994), Sec. 102.

40 For more on the Federal Reserve's position, see Alan Greenspan, "No Single Regulator for Banks," Wall Street Journal, November 15, 1993, p. A16.

41 Barth and Brumbaugh, p. 3; Robert Pasley, "Consolidation of the Federal Banking Regulatory Agencies," Annual Review of Banking Law, IX 1990 (Boston: Butterworth Legal Publishers, 1990), 274-276. Pasley argues that a separate regulator for home lending is not needed to encourage the continued flow of credit to home buyers, as originally sought by the Federal Home Loan Bank Act of 1933. Instead, the tax benefits and subsidies currently granted to the entire home loan industry could simply be authorized for any lender making a significant number of home loans.

42 Carron, p. 11; Newman, p. 10; Pasley, pp. 291 and 306.

43 S. 1895 , Sec. 104 (a) and (b). The consolidation plan authored by Senators Riegle and D'Amato would give commissioners six-year terms. See S. 1633 Sec. 103 (b)(1), (b)(2), and (c)(1).

44 Brumbaugh, p. 12.

45 Newman, p. 11.
46 Some policy makers have argued that, should the stock market plunge as it did in October 1987, many of the biggest banks in the country could rupture due to their extensive derivative activities. Few of these banks would have to fail before the federal govemment's responsibility for replacing deposits would render the insurance fund insolvent. See Kenneth Bacon, "Lawmakers Question Agencies' Ability to Regulate the Derivatives Market," Wall Street Joumal, October 29, 1993, p. A4, and Steven Lipin, "Regulators Seek More Bank Data On Derivatives," Wall Street Joumal, March 11, 1994, p. A2.

47 Newman, p. 11.

48 Ibid., p. 11.

49 Nationally chartered banks, state member banks, federal savings associations, and state savings associations all carrying FDIC insurance are nonetheless supervised by agencies other than the FDIC. See Federal Reserve Bank of New York and Board of Govemors of the Federal Reserve System, p. A-11.

50 The percentages used here have been rounded and do not include thrifts or thrift assets. See Board of Governors of the Federal Reserve System, p. A-11.

51 s. 1895 , Sec. 307.

52 Newman, p. 8; Ricki Tigert, nominee to head the FDIC, testifying before the Senate Banking Committee, February 1, 1994. Despite the assurances of Undersecretary Newman and Ms. Tigert, the Regulatory Consolidation Act of 1994 provides the FDIC nowhere near the latinde granted to the Federal Reserve with regard to back-up examination authority. In order to balance the independence of the proposed Federal Banking Commission with the legitimate need for back-up authority on the part of the Fed and the FDIC, Congress should distribute this balance of power with greater equity and clarity than the administration has in RCA. See S. 1895, Sec. 201 (c), (d), Sec. 308, and Sec. 309.

\section{Bibliography}

Bacon, Kenneth, "Administration Proposes Combining Four U.S. Agencies' Banking Functions," Wall Street Joumal, November 24, 1993.

Bacon, Kenneth, 'Lawmakers Question Agencies' Ability to Regulate the Derivatives Market," Wall Street Journal, October 29, 1993.

Barth, James R., and R. Dan Brumbaugh, Jr., "Merging Regulators Will Help Banks Compete," American Banker, December 2, 1993.

Board of Governors of the Federal Reserve System, The Views of the Board of Governors of the Federal Reserve System on the Consolidation of Bank Supervision and Regulation (Washington, D.C.: Federal Reserve System, March 1994).
Bowsher, Charles A., Document No. GAO/T-AFMD-90-15, Resolving the Savings and Loan Crisis: Billions More and Additional Reforms Needed (Washington, D.C.: U.S. GAO, April 6, 1990).

Brumbaugh, Jr., R. Dan, former Deputy Chief Economist of the Federal Home Loan Bank Board, testifying before the Senate Banking Committee, March 4, 1994.

Carron; Andrew S., Reforming the Bank Regulatory Structure (Washington, D.C.: The Brookings Institution, 1984),

Federal Reserve Bank of New York, Depository Institutions and Tbeir Regulators (New York: Federal Reserve Bank of New York, April 1990).

Financial Insititutions Reform, Recovery, and Enforcement Act of 1989, Pub. L. No. 101-73, 103 Statute 183 (codified in scattered sections of 12 and 15 U.S.C.). 
Granelli, James S., "Keating, Son Guilty of Federal Charges," Los Angeles Times, January 7, 1993.

Greenspan, Alan, "No Single Regulator for Banks," Wall Street Joumal, November 15, 1993.

Greider, William, Secrets of the Temple: How the Federal Reserve Runs the Country (New York: Simon and Schuster, 1987).

H.R. 1214, 103rd Cong., 1st Sess. (1993).

Jackson, Brooks Honest Graft: Big Money and the American Polit- . ical Process (Washington, D.C.: Farragut Publishing Co., 1990).

Knight, Jerry, "House Approves Funds to Finish Thrift Cleanup," Washington Post, November 23, 1993.

Lipin, Steve, "Regulators Seek More Data On Derivatives," Wall Street Journal, March 11, 1994.

Newman, Frank, Undersecretary of the Treasury, Consolidating the Federal Bank Regulatory Agencies (Washington, D.C.: U.S. Department of the Treasury, November 23, 1993).

Pasley, Robert, "Consolidation of the Federal Banking Regulatory Agencies," Annual Review of Banking Law, IX 1990. (Boston: Butterworth Legal Publishers, 1990).

Pizzo, Stephen, Mary Fricker, and Paul Muolo, Inside Job: The Looting of America's Savings and Loans (New York: Harper Perennial, 1991).

- Resolution Trust Corporation, Record No. 6901, FIRREA Functional Inter-relationships (Washington, D.C.: U.S. RTC, August 8, 1989).

"S\&L Bailout Funding Dries Up," Congressional Quarterly Al. manac, 1992 ed., Vol. 48 (Washington, D.C.: Congressional Quarterly, Inc., 1992).

S. 1633, 103rd Cong., 1st Sess. (1993).
S. 1895, 103rd Cong., 2nd Sess., reprinted in the Congressional Record (March 8, 1994).

Schlesinger, Tom, Director of the Southern Finance Project of Charlotte, N.C., interviewed on December 10, 1993.

Seidman, William L., "A New Way to Govern Banks," Wall Street Journal, February 3, 1994.

Sherrill, Robert, "The Looting Decade," The Nation, November $19,1990$.

Stevenson, Richard W., "Keating Convicted of Securities Fraud in S\&I's Collapse," New York Times, December 5, 1991.

Tigert, Ricki Rhodarmer, nominee to head the Federal Deposit Insurance Corporation, testifying before the U.S. Senate Committee on Banking, Housing,and Urban Affairs, February 1,1994 .

.U.S. Congress, House of Representatives Report No. 54(I), 101st Cong., 1st Sess.,reprinted in United States Code Congressional and Administrative News, 1989, Public Law 101-73 Legislative History (St. Paul, Minn.: West Publishing Company, 1990).

U.S. Congress, House, various representatives debating H.R. 1278, 101st. Cong., 1st Sess., Congressional Record (June 1415,1989).

U.S. Congress, Senate, various senators debating S. 413, 101st. Cong., 1st Sess., Congressional Record (April 17-19, 1989).

U.S. Department of the Treasury, Modernizing the Financial System: Recommendations for Safer, More Competitive Banks (Washington, D.C.: GPO, February 1991).

White, Lawrence J., The SEL Debacle: Policy Lessons, for Bank and Thrift Regulation (New York: Oxford University Press, 1991). 


\section{Appendix A}

Presented is a graphic overview of the numerous agencies and requirements imposed by enactment of the Financial Institutions Reform, Recovery, and Enforcement Act (FIRREA) of 1989. The acronyms and abbreviations used refeer to the following agencies and organizations:

APPRAISAL SUBCOMMITIEE - Appraisal Subcommittee of the Federal Institution Examination Council

ATTY GEN - Attorney General

CREDIT STANDARDS COMMTTTEE - Credit Standards Advisory Committee

FDIC - Federal Deposit Insurance Corporation

FHIMC - Federal Home Loan Mortgage Corporation

FHFB - Federal Housing Finance Board

FNMA - Federal National Mortgage Association

FRS - Federal Reserve System
GAO - General Accounting Office

HUD - Department of Housing and Urban Development

NCUA - National Credit Union Administration

OCC - Office of the Comptroller of the Currency

OTS - Office of Thrift Supervision

RFC - Resolution Funding Corporation

RTC - Resolution Trust Corporation

TREAS - Treasury Department

SAIF COMMITTEE - Savings Association Insurance Fund Industry Advisory Committee

FIRREA

FUNCTIONAL INTERRELATIONSHIPS

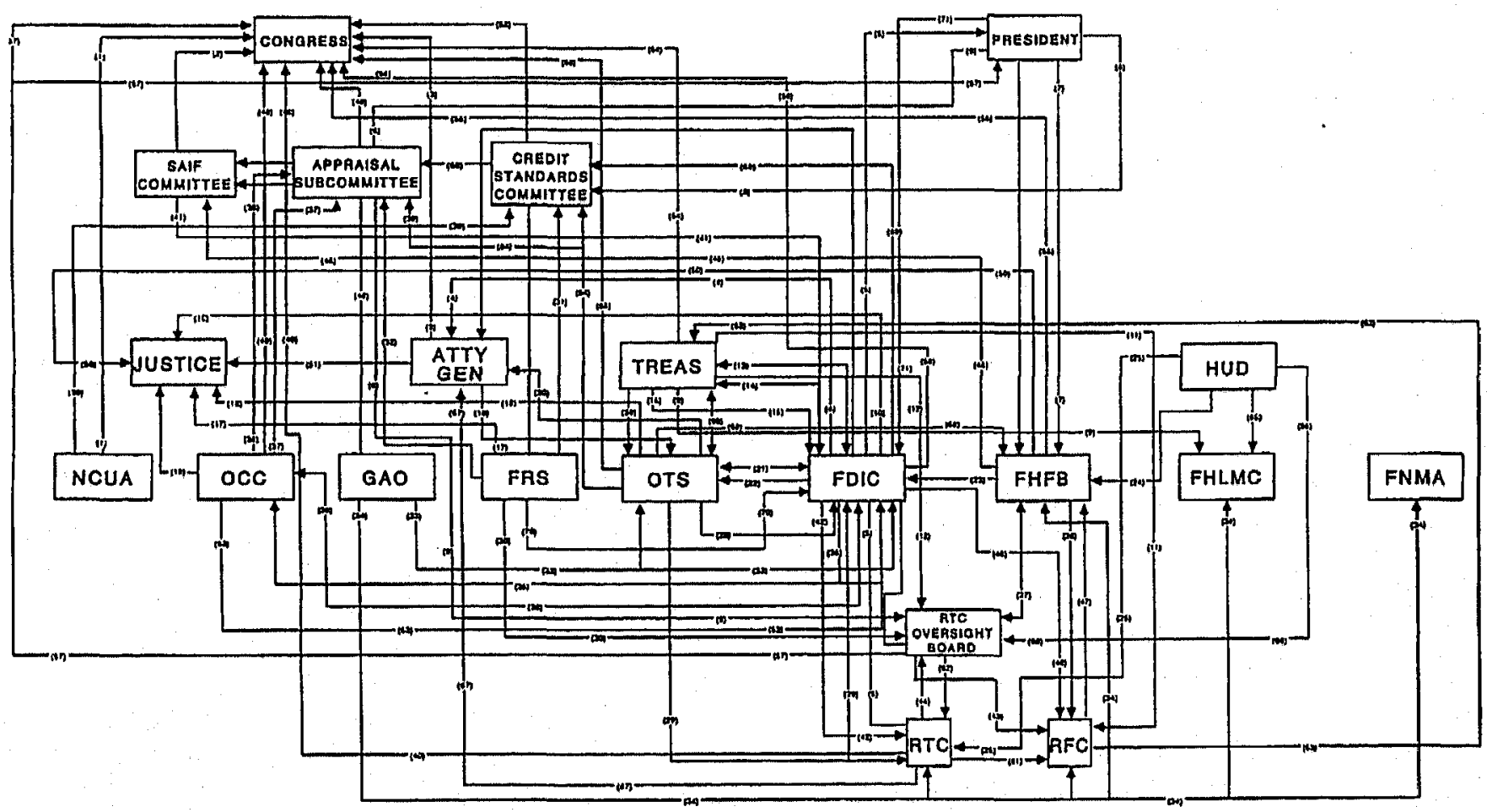

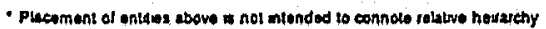

Reprinted with permission, RTC, 1994 